OPEN ACCESS

Edited by:

Maritza Sepulveda

Universidad de Valparaiso, Chile

Reviewed by:

Clément Chion,

University of Quebec in Outaouais,

Canada

Joan Gonzalvo

Tethys Research Institute, Italy

*Correspondence:

Jorge Urbán $R$

jurban@uabcs.mx

Specialty section:

This article was submitted to

Marine Megafauna,

a section of the journal

Frontiers in Marine Science

Received: 31 October 2020

Accepted: 24 February 2021

Published: 07 April 2021

Citation:

Urbán RJ and Viloria-Gómora L (2021) Challenges of Whale Watching and Swim With Dolphins in Mexico.

Front. Mar. Sci. 8:624596.

doi: 10.3389/fmars.2021.624596

\section{Challenges of Whale Watching and Swim With Dolphins in Mexico}

\author{
Jorge Urbán R.* and Lorena Viloria-Gómora \\ Departamento de Ciencias Marinas y Costeras, Universidad Autónoma de Baja California Sur, La Paz, Mexico
}

Mexico is one of the top 10 whale-watching destinations in the world. The target species for "whale watching" (WW) are the gray whale, blue whale, humpback whale, and fin whale; the target species for "swim with dolphins" (SWD) are the bottlenose dolphin, spotted dolphin, spinner dolphin, and killer whale. WW has an increment of $666 \%$ income, $94 \%$ of trips, and $51 \%$ in the jobs generated in the last 11 years. Although Mexican legislation to regulate WW appears to be well designed, the great challenge is applying this normative in the field. In particular, it has been observed that surveillance and enforcement of normative differ significantly whether WW has carried out within a Marine Protected Area (MPA) or area without such designation. WW of gray and blue whales in El Vizcaíno Biosphere Reserve and Bahía de Loreto National Park, respectively, is developed within the MPAs. They are considered examples of acceptable WW practices. In contrast, in places without protected status as Puerto Vallarta, Jal., and Los Cabos, Baja California Sur (BCS), the WW practices have different problems related to boats' presence without permission as sport fishing boats, private boats, and jet skis that do not respect WW guidelines. On the other hand, creating normativity or policies to regulate SWD in Mexico represents a current challenge. It is also a challenge to promote that local communities are involved in carrying out WW and SWD and are included in granting permits and the jobs and benefits of the economic spillover that these tourist activities generate.

Keywords: whales, dolphins, whale watching, normativity, Mexico, Turismo

\section{INTRODUCTION}

Mexico is one of the top 10 whale-watching (WW) global destinations. It is the first in Latin America and the second in the American continent after the United States (Hoyt and Iñíguez, 2008). The first trips were in 1970 when ships filled with United States tourists departing from San Diego traveled on self-contained 7- to 10-day cruises down the Baja California coast to reach San Ignacio's lagoons Ojo de Liebre (Hoyt, 2008). In the late 1980s, the local communities around gray whales' breeding lagoons from the west coast of the Baja California Peninsula began to profit from WW using their boats. WW grew as a diverse industry. In the 1990s, it spread from the western to the eastern coast of the peninsula, from the lagoons to Loreto Bay, attracted by blue whales. The WW moved to the mainland coast, especially to Bahía de Banderas in Jalisco and Nayarit's states drawn by humpback whales. At the beginning of the century, it expanded north to Todos Santos Bay in front of Ensenada, taking advantage of gray whales' migration. It grew south to Los Cabos, 
in the southern end of the Baja California Peninsula to use humpback whales. In the last decade, on the mainland coast, it began north in the Upper Gulf of California, taking advantage of fin whales' resident population (DOF, 2019) and started south in Guerrero and Oaxaca states to use humpback whales (DOF, 2015). Besides WW, another interaction with cetaceans was implemented as a tourist attraction: the "dolphins watching" (DW) and "swim with dolphins" (SWD). Both activities began in Jalisco in 2000, taking advantage of bottlenose dolphins. In Sinaloa, since 2015 on bottlenose, spotted, and spinner dolphins, and recently in Baja California Sur, in 2018 using killer whales.

In Mexico, WW of baleen whales and sperm whales is regulated by the 131 Official Mexican Standard, which was implemented in 1998 (NOM-131-SEMARNAT, 1998; DOF, 2011). Its objective is to minimize human activity's negative impact, following scientific reports and experiences in other countries. Cetaceans modify their behavior in the short term in the presence of tourist boats. For example, the actions record them spending less time on the surface, increase their diving time (Nowacek et al., 2001), swim faster (Williams et al., 2002; Lundquist et al., 2013), or show erratic movements (Senigaglia et al., 2016). Also, it is proposed that the noise generated by the engines of the boats can affect the vocalization patterns (Jensen et al., 2009), among other potential effects.

Even though WW in Mexico has grown explosively as in the rest of the world (Finkler and Higham, 2020), there are few systematic studies about WW. These papers are reduced to analyze WW on gray whales that arrive in Laguna de San Ignacio, Ojo de libre (Brenner et al., 2016), and Bahía Magdalena (Paredes-Lozano, 2016; Schwoerer et al., 2016). On the other hand, it should be noted that despite the adverse effects of WW being recorded in odontocetes (Bejder et al., 2006, IWC, 2007, Senigaglia et al., 2011), there is still no law to regulate the observation of dolphins in Mexico. There is also no regulation for swimming with whales or dolphins, despite the evidence on behavioral changes in this activity (Lundquist et al., 2013; Sprogis et al., 2020). This document aims to present an overview of WW in Mexico, based on published information, data provided by tour operators, non-governmental organizations, and our field experience since 1980 .

\section{WW TARGET SPECIES}

There are records of eight species of mysticetes in the Mexican Pacific, including the Gulf of California. Of those, three migratory-gray whale (Eschrichtius robustus), humpback whale (Megaptera novaeangliae), and blue whale (Balaenoptera musculus) - and one with a resident population within the Gulf of California, the fin whale (Balaenoptera physalus), is the target of WW in Mexico (Table 1 and Figure 1).

\section{Gray Whale, Eschrichtius robustus}

Gray whales occur most frequently in shallow coastal waters in the North Pacific. Two populations are recognized: the endangered western population of about 300 individuals that summer in the Okhotsk Sea in Russia; and the eastern population of more than 21,000 individuals that summer in the Bering, Chukchi, and Western Beaufort Seas (Swartz, 2018). Individuals from both populations migrate from their summer feeding grounds to their winter breeding and calving areas off the Baja California peninsula (Weller et al., 2012). The main wintering areas on the peninsula are the Ojo de Liebre Lagoon, San Ignacio Lagoon, and Magdalena Bay Lagoon complex (Urbán et al., 2003).

\section{Humpback Whale, Megaptera novaeangliae}

Humpback whales are distributed in all the world's oceans. It is a highly migratory species. It is distributed in its feeding areas during the spring-autumn, located in waters of middle or high latitudes. Later in winter, it goes to its delivery areas in the tropics (Clapham, 2018). Of the North Pacific population, an abundance of $21,808(\mathrm{CV}=0.04)$ has been estimated (Barlow et al., 2011). Although the structure of this population is not clear, some migratory connections have been established. The reproductive groups distributed in the coasts of Japan, Hawaii, and the north of the Mexican Pacific (Baja California-Nayarit) feed mainly on the Kamchatka Peninsula, the Bering Sea, and the Gulf of Alaska. In the winter nursery areas of southern Mexico and Central America, they feed in Canada and the United States (Calambokidis et al., 2008; Baker et al., 2013). In the Mexican Pacific, humpback whales aggregate at the southern tip of the Baja California peninsula, particularly between Cabo Pulmo and Cabo San Lucas, around the Tres Marías Islands and Isla Isabel, and off the mainland coast from Mazatlán to Chiapas (Central America) (Urbán et al., 2000).

\section{Blue Whale, Balaenoptera Musculus}

The blue whale is a wide-ranging species distributed throughout the world's oceans in the coastal, shelf, and oceanic waters (Sears and Perrin, 2018). The blue whales from the Eastern North Pacific population are summering in California and Oregon and migrate to the southwest coast of the Gulf of California from Loreto to Los Cabos during winter and spring (Urbán, 2010). Nevertheless, there are records of blue whales during all seasons as north as the Midriff Islands (SEMARNAT, 2018). Gendron and Gerrodette (2003) estimate the population size of 362 individuals $(\mathrm{CI}=47.5 \%)$ in the Gulf of California.

\section{Fin Whale, Balaenoptera physalus}

Fin whales are found in all the world's oceans from the equator to polar regions; the largest concentrations are temperate and cold waters (Aguilar and García-Vernet, 2018). There is a resident population of fin whales in the Gulf of California (Bérubé et al., 2002; Urbán et al., 2005) with a generalized pattern of distribution: in the northern Gulf and from Canal de Ballenas to Bahía de La Paz in winter and spring; and in the Midriff Islands and Bahía de La Paz in summer and fall. The fin whale population size in the Gulf of California has been estimated at 656 individuals (95\% CI 374-938) (Díaz-Guzmán, 2006). 
TABLE 1 | Sites, species, and periods of WW and SWD in Mexico.

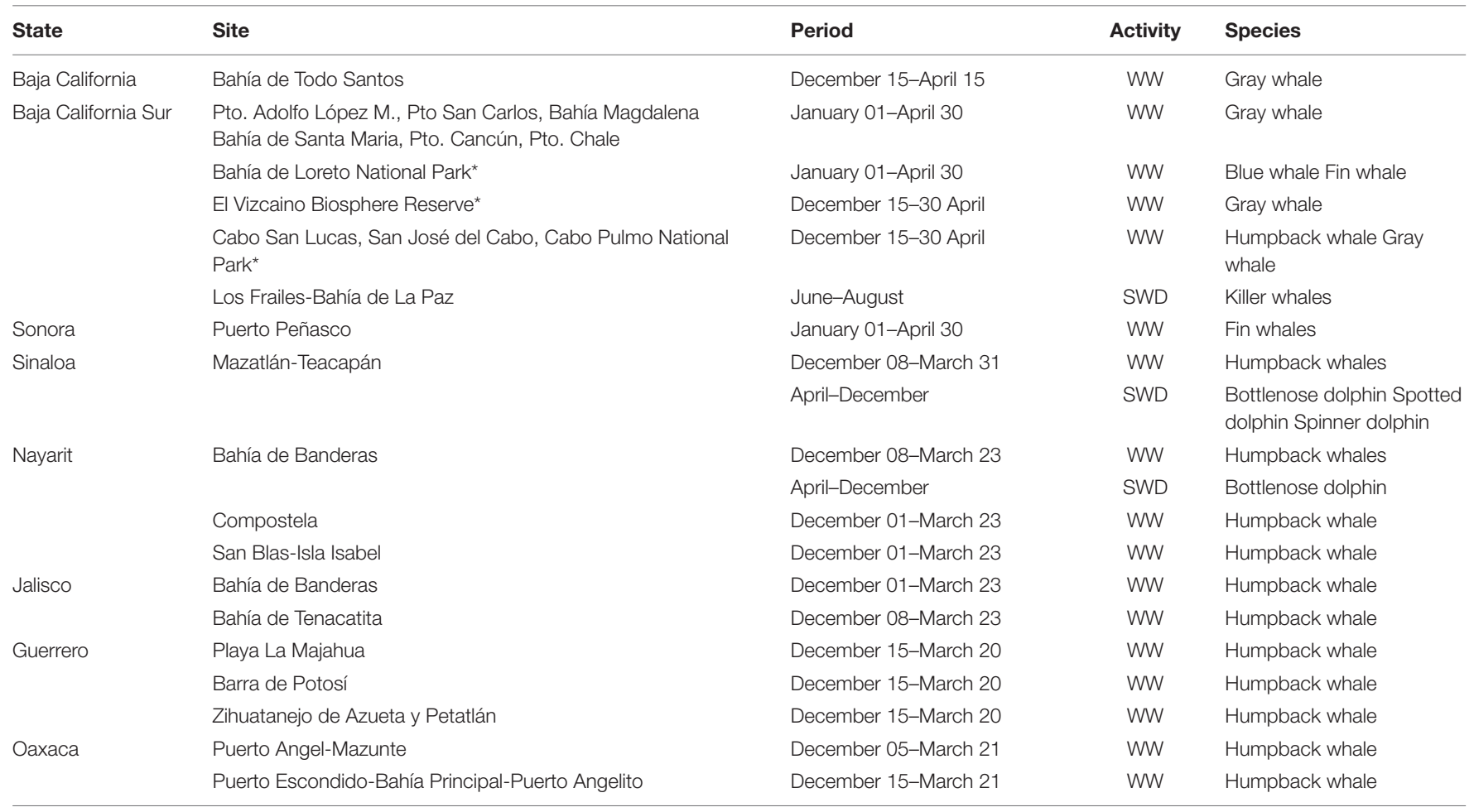

*Marine protected area.

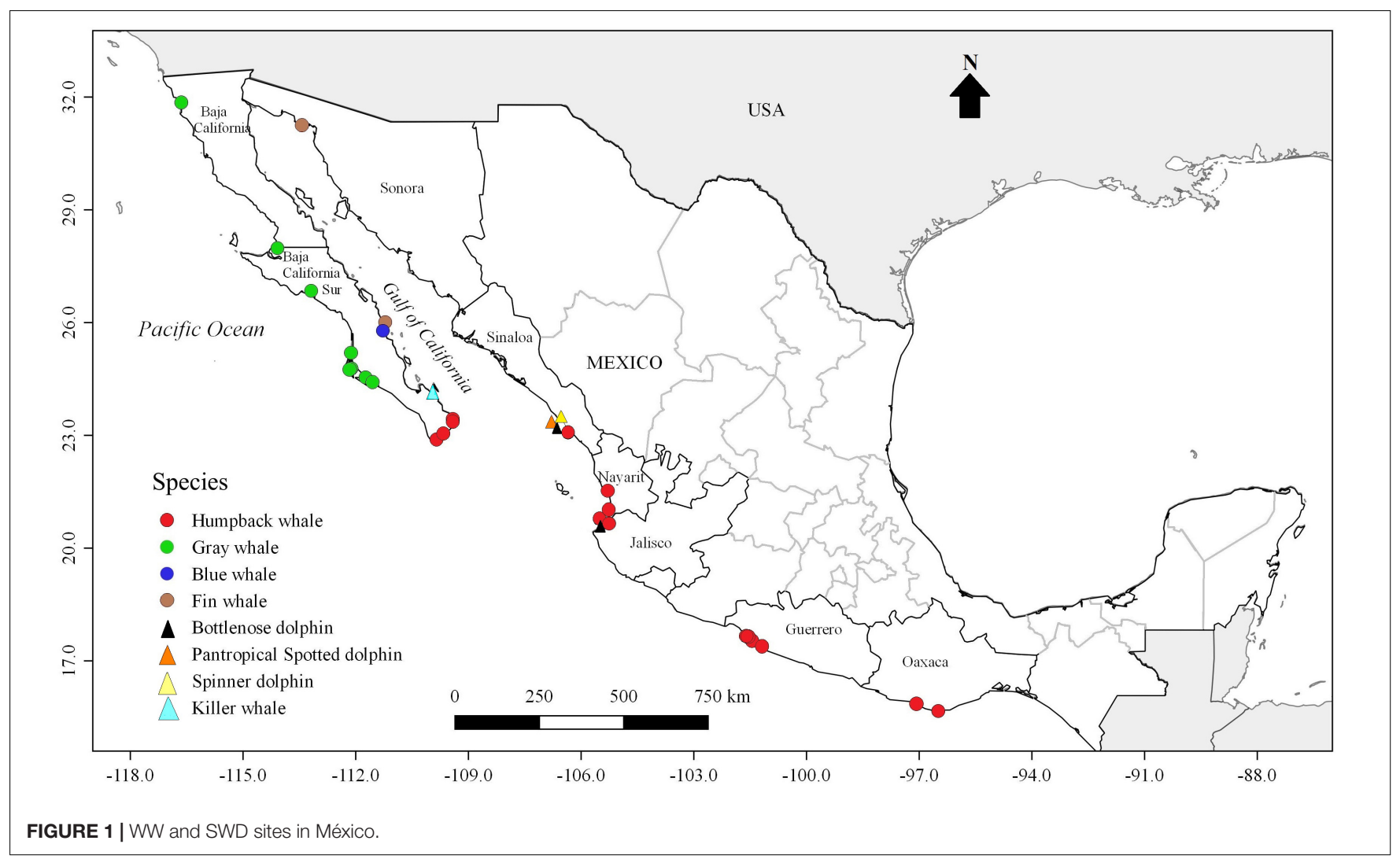




\section{SWD AND DW AND TARGET SPECIES}

Regarding the odontocetes, of the 25 species distributed in the Mexican Pacific (Medrano and Urbán, 2018), four species are targeted to SWD: the bottlenose dolphin (Tursiops truncatus), the spotted dolphin (Stenella attenuata), the spinner dolphin (Stenella longirostris), and the killer whales (Orcinus orca) (Table 1 and Figure 1). There are no DW companies with specific target species. The DW is complimentary during WW or SWD trips.

\section{Bottlenose Dolphin, Tursiops truncatus}

Bottlenose dolphins exist worldwide in temperate and tropical waters, with populations occurring in coastal waters, around islands and atolls, and over shallow banks and offshore in deep water (Wells and Scott, 2018). Differences in morphology, feeding habits, and parasite loads suggest at least two distinctive forms, coastal and offshore, in the eastern North Pacific and the Gulf of California (Walker, 1981; Díaz-Gamboa, 2003). This species is one of the most frequently seen dolphins. The bottlenose dolphins related to the DW and SWD belong to the coast. There is an estimated $33,799(95 \% \mathrm{CI}=20,500-58,358)$ to the Gulf of California (Gerrodette and Palacios, 1996).

\section{Pantropical Spotted Dolphin, Stenella attenuata}

Pantropical spotted dolphins are found throughout the world's tropical and subtropical regions, between about $40^{\circ} \mathrm{N}$ and $40^{\circ} \mathrm{S}$ (Jefferson et al., 2015). It is the most-abundant dolphin in the Gulf of California and southern Mexico, especially off the coasts from Sinaloa to Chiapas. Two subspecies of the pantropical spotted dolphin (the offshore species, S. attenuata attenuata, and the coastal $S$. attenuata graffmani) have been identified in the Eastern Tropical Pacific (Perrin and Hohn, 1994). Although the coastal species is most common, both species' records have been documented on Mexico's coasts. The spotted dolphins related to the DW and SWD belong to the subspecies S. attenuata graffmani. The abundance estimation of this species in the Eastern Tropical Pacific is around 640,000 individuals (Perrin, 2018a).

\section{Spinner Dolphin, Stenella longirostris}

Spinner dolphins are found around the world in tropical waters (Jefferson et al., 2015). The observations of this species in the Mexican Pacific, including the Gulf of California, belong to the subspecies S. longirostris orientalis, and possible S. longirostris centroamericana described in the Eastern Tropical Pacific (Perrin and Gilpatrick, 1994). The spinner dolphins related to the DW and SWD belong to the subspecies $S$. longirostris orientalis. Abundance estimates of this species in the Eastern Tropical Pacific are around 800,000 individuals (Perrin, 2018b).

\section{Killer Whale, Orcinus orca}

Killer whales, or orcas, are the world's most widespread mammal, found from the tropics to high latitudes in both hemispheres and oceanic and coastal areas (Ford, 2018). Between 1973 and 2013,
246 sightings were reported, including 246 individuals photoidentified throughout the Gulf of California. Group size ranged from 1 to 45 animals, with an average of 5.6 individuals per group (Guerrero-Ruiz, 2013). Five resident "pods" of killer whales have been documented in the Gulf of California (González-Ruelas, 2016). Recently, it was proposed that the killer whales from the Mexican Pacific belong to the ecotype "Eastern Tropical Pacific" (Vargas-Bravo et al., 2020).

\section{WW AND SWD PLACES AND SEASONS}

The Environment and Natural Resources Ministry from Mexico (SEMARNAT) publishes every year the places and periods where WW is permitted (e.g., DOF, 2020). The timing of the WW season depends on the time of the arrival of the migratory species and the latitude of the WW place (Figure 1 and Table 1).

The humpback whale is the species with more WW official sites (21), including Baja California Sur, Sinaloa, Jalisco, Nayarit, Guerrero, and Oaxaca. This species' sighting is carried out from boats of different sizes, that is, from small ships of $23 \mathrm{ft}$ to catamarans of $75 \mathrm{ft}$. The second species with more WW official sites is the gray whale (9), including Baja California and Baja California Sur. WW is performing during the migration in the open sea to and from the breeding lagoons. While in Ensenada, Baja California, medium-sized boats are permitted, in the breeding lagoons, BCS, only small ships of $22-27 \mathrm{ft}$. named "pangas" are allowed. There are two WW official sites for the fin whale: Loreto on the east coast of BCS and in the Upper Gulf of California on Sonora's coast, where pangas and mediumsized boats are permitted. Finally, the blue whale has only one WW official site in Loreto on the east coast of BCS, and only pangas are allowed.

On the other hand, there are no official observation sites for SWD. The swim with bottlenose dolphins is done in Sinaloa and Jalisco, using pangas from May to December. The swim with spotted and spinner dolphins is done in Sinaloa, using pangas and farther from the shore than the bottlenose dolphins. The swim with orcas is done on the southeast coast of BCS, using small airplanes to localize the orcas and pangas to approach and swim with them. The activity is done in summer when the mobulas (Mobula mobular) arrive in this area, and the orcas feed on them.

\section{DEVELOPMENT OF WW IN MEXICO IN THE LAST 10 YEARS}

The SEMARNAT (2020) reported that WW activity increased in the last 10 years (2009-2019), by $666 \%$ in income, $94 \%$ in the number of trips, and $51 \%$ in the jobs generated. WW targeting humpback whales is the one that caused the most revenue, travels, and employment in 2019. For example, of the total profits (US $\$ 7,782,602$ ) with the three species (humpback, gray, and blue whale), $81 \%$ corresponds to the WW with the humpback whale, as well as $68 \%$ of the trips and $74 \%$ of the work (Figure 2).

Such a growth rate suggests that this tourism industry has growth potential in the current decade. At the same time, it 


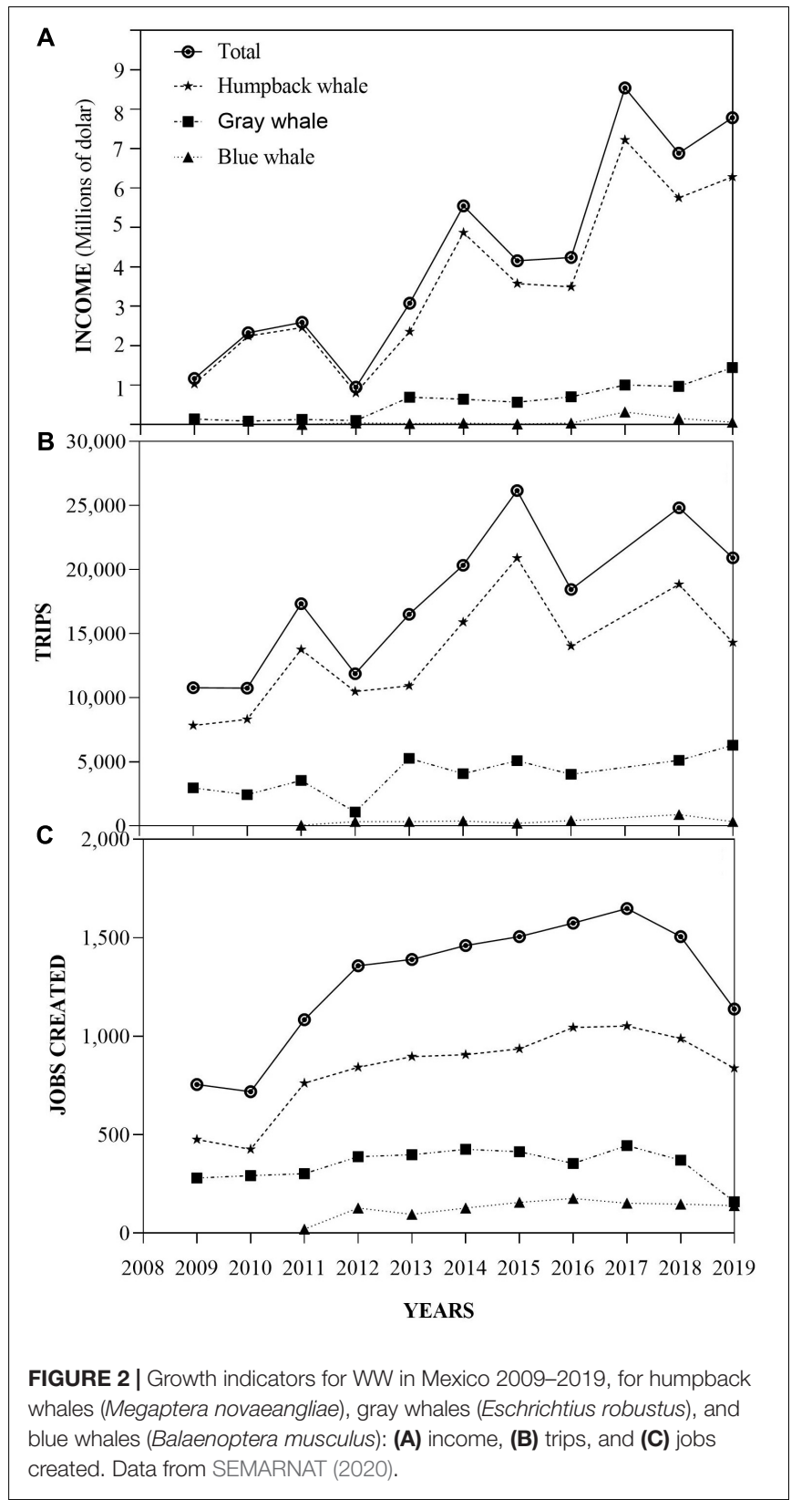

represents a potential increase in the number of boats and people seeking to access the whales' environment and get closer to the whales themselves. Unfortunately, there are no systematic records or studies that help in the modeling of upcoming scenarios. It is discouraging to think of excessive growth in the whale resource's use and the inappropriate use of the marine environment in the current context.

Remarkably, the economic gains generated by WW of the humpback whale can be attributed to its biological characteristics. This species mainly shows high activity on the surface, displaying showy movements. The whales' widest distribution has led to numerous sighting points in different locations in the Mexican Pacific. Such development of the WW industry around this species supposes major pressure, so it also demands scientific studies that record WW's effects.

\section{LEGAL MEXICAN FRAMEWORK}

In Mexico, all marine mammals are protected by the Official Mexican Standard 059 (DOF, 2002a), which includes the risk category and promotes conservation actions for each species. In 2002, Mexico signed a decree that establishes a refuge for great whales in all the Mexican territory's marine areas and the waters where Mexico exercises its sovereignty and jurisdiction (DOF, 2002b). That same year, the General Wildlife Law prohibited the extractive use of any marine mammal. It began to promote non-extractive use to conserving marine mammals and favoring the sustainable development of the population and regional economies (LGVS, 2002).

The Official Mexican Standard 131 (DOF, 2011) establishes guidelines and specifications for developing WW activities (mysticetes and sperm whales) to protect and conserve the whales and their habitat. Depending on the species, vessels must respect the minimum distances established (between 60 and $100 \mathrm{~m}$ ) and maintain speeds below $9 \mathrm{~km} / \mathrm{h}$ when entering the whale or dolphin watching area and $4 \mathrm{~km} / \mathrm{h}$ during the WW. Boats should also avoid sudden changes in direction and speed. A maximum of four ships can approach a single whale or group of whales at a time, among other specifications.

In the Mexican legislation, there are no regulations for DW or swimming with whales or dolphins. In the dolphins' case, more and more tourism service providers advertise these tours on their internet pages. In swimming with humpback whales, so far, there are no announcements about these types of tours, but it is known that "opportunistic" events occur with increasing frequency.

\section{CONCLUSIONS}

The Mexican Pacific encompasses subtropical and tropical waters from the Northeast Pacific and are the migratory destination of three of the most attractive whales in WW: the blue whale, the gray whale, and humpback whale. The distribution area for the resident population of fin whales is in the Gulf of California all year. The regular presence of whales, proximity to shore, and good weather have been essential in developing WW in this country.

Legislation to regulate WW in Mexico is considered well designed and aims to minimize tourist activity. In Mexico, no specific investigations have been carried out to know the short-, medium-, and long-term impact of this activity. However, the current legislation is governed by the precautionary principle and the results of other countries' investigations (Nowacek et al., 2001; Williams et al., 2002; Jensen et al., 2009; Lundquist et al., 2013).

Although the Mexican legislation about the marine mammals, and specifically with the WW in Mexico, is good, the great challenge is to apply the normativity in the field. Since the MPAs 
responsibilities are to monitor and evaluate $\mathrm{WW}$ activities, there is a significant difference in WW surveillance degree depending on if they are happening an MPA or not. In the case of gray whales in the Ojo de Liebre and San Ignacio Lagoons, which are part of the El Vizcaíno Biosphere Reserve, they are considered examples of good WW practices in the world (Hoyt, 2011; IWC, 2018). The only official WW site for blue whales is located in another MPA, the Bahía de Loreto National Park. Another example of good practices, where passive observation is conducted, is a novel way of approaching and observing whales (IWC, 2018).

On the other hand, the remaining official WW sites for humpback whales (20 sites, Table 1) are not within MPAs, except Cabo Pulmo National Park. In the case of Puerto Vallarta, Jal., and Los Cabos, BCS-the two most important tourist destinations WW with humpback whales in Mexico-tour operators with a WW permit must take a training course to follow all the guidelines of NOM-131. But the problem is with boats that are not licensed and do WW activities, such as sport fishing boats, private yachts, and jet skis.

These site situations become complex since low or no surveillance, economic interest, and low respect for nature make these sites dangerous for people and humpback whales. To mitigate this situation, civil associations give training workshops to WW tour operators and activate campaigns such as "Sail with caution in whale season" by Whale Ecology and Conservation (ECOBAC AC) in Puerto Vallarta. Our research group PRIMMA (Marine Mammal Research Program) has given courses on good WW practices aimed at the local communities and tourism service providers (in Puerto Chale, Puerto Peñasco, Bahía Magdalena, Los Cabos, among others). Despite the efforts, the results have not yet been perceived, which is why an intense campaign to raise awareness about the impact of WW's bad practices is necessary. In this campaign, all key stakeholders (authorities, tour operators, tourists, scientists, fishermen, etc.) should be involved and act in consequence.

Another strategy on a larger scale in time and space is to create more MPAs covering areas with high WW activity, such as the Los Cabos region. We elaborated the proposals of three priority areas for the conservation and management of great whales. One on the west coast of the Baja California Peninsula from Laguna San Ignacio to Bahía Magdalena focused on gray whales (Viloria-Gomora et al., in press). Another around the tip of the Baja California Peninsula from Cabo San Lucas to Cabo Pulmo focused on humpback whales (Urbán et al., in press-a). And in the east coast from Loreto to Cabo Pulmo with an emphasis on blue whales, fin whales, humpback whales, and killer whales

\section{REFERENCES}

Aguilar, A., and García-Vernet, R. (2018). "Fin Whale Balaenoptera physalus," in Encyclopedia of Marine Mammals, eds B. Würsig, J. G. M. Thewissen, and K. Kovacs (San Diego, CA: Academic Press), 368-371. doi: 10.1016/B978-0-12804327-1.00128-X

Baker, C. S., Steel, D., Calambokidis, J., Falcone, E., González-Peral, U., Barlow, J., et al. (2013). Strong maternal fidelity and natal philopatry shape genetic
(Urbán et al., in press-b). The next steps for these documents will be to submit them to the Mexican government to consider their eventual acceptance.

There is a need for SWD regulations that establish rules to make the activity safe, both for humans and dolphins. The companies that currently offer SWD in Mexico adopted laws that are followed in other countries, including no touching dolphins, not feeding them, not swimming in groups of feeding dolphins, and not swimming in groups where more than 50\% are calves, among others (Lewis and Walker, 2018). It is to standardize procedures for the different species and sites where SWD is performed. Today there is a consensus among the SWD stakeholders to create an Official Mexican Standard with the normativity and policies of the SWD appropriate to Mexico. Finally, another challenge in Latin America, Mexico included, is promoting WW and SWD acceptable practices, involving the local communities in these tourism activities to include them in the permits granted, jobs generated, and benefits of the increasing income.

\section{DATA AVAILABILITY STATEMENT}

Publicly available datasets were analyzed in this study. This data can be found here: http://dgeiawf.semarnat.gob.mx:8080/ ibi_apps/WFServlet?IBIF_ex=D3_BIODIV03_15\&IBIC_user= dgeia_mce\&IBIC_pass=dgeia_mce\&NOMBREENTIDAD $=^{*}$.

\section{ETHICS STATEMENT}

Ethical review and approval was not required for the animal study because it is not necessary, the study is about a tourism activity related to whales.

\section{AUTHOR CONTRIBUTIONS}

Both authors: conceptualization, funding acquisition, writingoriginal draft, and writing - review and editing.

\section{ACKNOWLEDGMENTS}

We thank Mario Gómez, Oscar Guzón Onca Explorations ${ }^{\circledR}$ (2020), and María Eugenia (Wildlife Connection $\left.{ }^{\circledR}, 2020\right)$ for the valuable information provided for this article about swimming with dolphins and killer whales.

structure in North Pacific humpback whales. Mar. Ecol. Prog. Ser. 494, 291-306. doi: 10.3354/meps 10508

Barlow, J., Calambokidis, J., Falcone, E., Baker, S. C., Burdin, A. M., Clapham, P. J., et al. (2011). Humpback whale abundance in the North Pacific estimated by photographic capture-recapture with bias correction from simulation studies. Mar. Mam. Sci. 27, 793-818. doi: 10.1111/j.1748-7692.2010.00444.x

Bejder, L., Samuels, A., Whitehead, H., and Gales, N. (2006). Decline in relative abundance of bottlenose dolphins expose ed to long-term 
disturbance. Conserv. Biol. 20, 1791-1798. doi: 10.1111/j.1523-1739.2006. 00540.x

Bérubé, M., Urbán, J., Dizon, A. E., Brownell, R. L., and Palsbøll, P. J. (2002). Genetic identification of a small and highly isolated population of fin whales (Balaenoptera physalus) in the Sea of Cortez, Mexico. Conserv. Genet. 3, 183190. doi: $10.1023 / \mathrm{A}: 1015224730394$

Brenner, L., Mayer, M., and Stadler, C. (2016). The economic benefits of whale watching in El Vizcaíno Biosphere Reserve, Mexico. Economía Sociedad Territorio 16, 429-457. doi: 10.22136/est002016637

Calambokidis, J., Falcone, E., Quinn, T., Burdin, A. M., Clapham, P. J., Ford, J., et al. (2008). SPLASH: Structure of Populations, Levels of Abundance and Status of Humpback Whales in the North Pacific. Final Report. Olympia, WA: Cascadia Research Collective.

Clapham, P. J. (2018). "Humpback wahale, Megaptera novaeangliae," in Encyclopedia of Marine Mammals, eds B. Würsig, J. G. M. Thewissen, and K. Kovacs (San Diego, CA: Academic Press), 489-492. doi: 10.1016/B978-0-12804327-1.00154-0

Díaz-Guzmán, C. (2006). Abundancia y Movimientos del Rorcual Común, Balaenoptera Physalus, en el Golfo de California. Ph. D. Thesis, Universidad Nacional Autónoma de México, México.

Díaz-Gamboa, R. (2003). Diferenciación entre Tursiones Tursiops truncatus Costeros y Oceánicos en el Golfo de California por Medio de Isótopos estables de Carbono y Nitrógeno. Ph. D. Thesis, Instituto Politécnico Nacional, Centro Interdisciplinario de Ciencias Marinas, La Paz.

DOF (2002b). Acuerdo por el que se establece como Area de Refugio para Proteger a las Especies de Grandes Ballenas de los Subórdenes Mysticeti y Odontoceti, las Zonas Marinas que Forman parte del Territorio Nacional y Aquellas Sobre las que la Nación Ejerce su Soberanía y Jurisdicción. Quezon: Secretaria de Medio Ambiente y Recursos Naturales.

DOF (2002a). Norma Oficial Mexicana NOM-059-SEMARNAT-2001, Norma de Protección Ambiental-Especies Nativas de México de Flora y Fauna SilvestresCategorías de Riesgo y Especificaciones para su Inclusión, Exclusión o CambioLista de Especies en Riesgo. Quezon: Secretaria de Medio Ambiente y Recursos Naturales.

DOF (2011). Norma Oficial Mexicana NOM-0131-SEMARNAT 2010, Que Establece Lineamientos y Especificaciones para el Desarrollo de Actividades de Observación de Ballenas, Relativas a su Protección y la Conservación de su Hábitat. Quezon: Secretaria de Medio Ambiente y Recursos Naturales.

DOF (2015). Aviso de Inicio de Temporada de Observación de Ballenas. Available online at: http://dof.gob.mx/nota_detalle.php? codigo=5409958\&fecha=30/09/ 2015 (accessed October 15, 2020).

DOF (2019). Aviso de Inicio de Temporada de Observación de Ballenas. Available online at: http://dof.gob.mx/nota_detalle.php?codigo $=5573751 \&$ fecha $=27 / 09 /$ 2019 (accessed October 15, 2020).

DOF (2020). Aviso de Inicio de Temporada de Observación de Ballenas. Available online at: http://www.dof.gob.mx/nota_detalle.php?codigo $=5602280 \&$ fecha $=$ 09/10/2020 (accessed October 15, 2020).

Finkler, W., and Higham, J. E. (2020). Stakeholder perspectives on sustainable whale watching: A science communication approach. J. Sustain. Tour. 28, 535-549. doi: 10.1080/09669582.2019.1684930

Ford, J. K. B. (2018). "Killer whale Orcinus orca," in Encyclopedia of Marine Mammals, eds B. Würsig, J. G. M. Thewissen, and K. Kovacs (San Diego, CA: Academic Press), 531-537. doi: 10.1016/B978-0-12-804327-1.00010-8

Gendron, D., and Gerrodette, T. (2003). "First abundance estimates of blue whales in Baja California waters from ship and aerial surveys," in Proceedings of the 15th Biennial Conference on the Biology of Marine Mammals, Greensboro.

Gerrodette, T., and Palacios, D. M. (1996). Estimates of Cetacean Abundance in EEZ Waters of the Eastern Tropical Pacific. La Jolla, CA: National Marine Fisheries Service. Administrative Report JL-96-10.27 p.

González-Ruelas, R. (2016). Residencia y Asociaciones de Orcas (Orcinus orca) en el Golfo de California. Ph. D. Thesis, Universidad Autónoma de Baja California Sur, La Paz.

Guerrero-Ruiz, M. (2013). Identidad Poblacional y Estructura Social de la orca Orcinus orca (Linnaeus 1758) en el Pacifico Mexicano. Ph. D. Thesis, Universidad Autónoma de Baja California Sur, La Paz.

Hoyt, E. (2008). "Whale watching," in Encyclopedia of Marine Mammals, eds B. Würsig, J. G. M. Thewissen, and K. Kovacs (San Diego, CA: Academic Press), 676-678.
Hoyt, E. (2011). Marine Protected Areas for Whales, Dolphins and Porpoises: A World Handbook for Cetacean Habitat Conservation and Planning. London: Routledge. doi: 10.4324/9781849771948

Hoyt, E., and Iñíguez, M. (2008). Estado del Avistamiento de Cetáceos en América Latina. Chippenham: WDCS.

IWC (2007). Report of the scientific committee. J. Cetacean Res. Manag. 9, 1-73.

IWC (2018). Online Whale Watching Handbook. Available online at: https:// wwhandbook.iwc.int/en/ (accessed September 11, 2020).

Jefferson, T. A., Webber, M. A., and Pitman, R. L. (2015). Marine Mammals of the World: A Comprehensive Guide to Their Identification, 2nd Edn. San Diego, CA: Academic Press.

Jensen, F. H., Bejder, L., Wahlberg, M., Soto, N. A., Johnson, M., and Madsen, P. T. (2009). Vessel noise effects on delphinid communication. Mar. Ecol. Prog. Ser. 395, 161-175. doi: 10.3354/meps08204

Lewis, S., and Walker, D. (2018). Global Best Practice Guidance for Responsible Whale and Dolphin Watching: Tourism Activities Involving Wild Cetaceans. A guide by the World Cetacean Alliance with support from ClubMed. Brighton: ClubMed.

LGVS (2002). Ley General de Vida Silvestre. Available online at: http://www. diputados.gob.mx/LeyesBiblio/pdf/146_190118.pdf (accessed September 30, 2020).

Lundquist, D., Sironi, M., Würsig, B., Rowntree, V., Martino, J., and Lundquist, L. (2013). Response of southern right whales to simulated swim-with-whale tourism at Península Valdés, Argentina. Mar. Mam. Sci. 29, E24-E45. doi: 10.1111/j.1748-7692.2012.00583.x

Medrano, G. L., and Urbán, R. J. (2018). Mamíferos Marinos: identidad, diversidad y conservación. Ciencia 70, 8-19.

Nowacek, S. M., Wells, R. S., and Solow, A. R. (2001). Short-term effects of boat traffic on bottlenose dolphins, Tursiops truncatus, in Sarasota Bay, Florida. Mar. Mam. Sci. 17, 673-688. doi: 10.1111/j.1748-7692.2001.tb01292.x

Onca Explorations ${ }^{\circledR}$. (2020). Swim with Dolphin in the Wild. Available online at https://oncaexplorations.com/site/ ((accessed october 29, 2020).

Paredes-Lozano, L. (2016). Análisis Integral del uso de la Ballena gris con fines Turísticos en Puerto Adolfo López Mateos, B. C. S. Ph. D. Thesis, Universidad Autónoma de Baja California Sur, La Paz.

Perrin, W. F. (2018a). "Pantropical spotted dolphin, Stenella attenuata, in Encyclopedia of Marine Mammals, eds B. Würsig, J. G. M. Thewissen, and K. Kovacs (San Diego, CA: Academic Press), 676-678. doi: 10.1016/B978-0-12804327-1.00189-8

Perrin, W. F. (2018b). "Spinner dolphin Stenella longirostris," in Encyclopedia of Marine Mammals, eds B. Würsig, J. G. M. Thewissen, and K. Kovacs (San Diego, CA: Academic Press), 925-928. doi: 10.1016/B978-0-12-804327-1. 00243-0

Perrin, W. F., and Gilpatrick, J. W. Jr. (1994). "Spinner dolphin Stenella longirostris (Gray, 1828)," in Handbook of Marine Mammals, eds S. H. Ridgway and R. Harrison (London: Academic Press), 99-128.

Perrin, W. F., and Hohn, A. A. (1994). "Spotted dolphin Stenella attenuata," in Handbook of Marine Mammals, eds S. H. Ridgway and R. Harrison (London: Academic Press), 71-98.

Schwoerer, T., Knowler, D., and Garcia-Martinez, S. (2016). The value of whale watching to local communities in Baja, Mexico: a case study using applied economic rent theory. Ecol. Econ. 127, 90-101. doi: 10.1016/j.ecolecon.2016. 03.004

Sears, R., and Perrin, W. F. (2018). "Blue whale Balaenoptera musculus," in Encyclopedia of Marine Mammals, eds B. Würsig, J. G. M. Thewissen, and K. Kovacs (San Diego, CA: Academic Press), 110-114. doi: 10.1016/B978-0-12804327-1.00070-4

SEMARNAT (2018). Programa de Acción para la Conservación de la Especie Ballena Azul (Balaenoptera musculus). México: SEMARNAT.

SEMARNAT (2020). Permisos, Viajes, Ingresos y Empleos Generados por la Observación de Ballenas por Especie. Available online at: http://dgeiawf. semarnat.gob.mx:8080/ibi_apps/WFServlet?IBIF_ex=D3_BIODIV03_15\& IBIC_user=dgeia_mce\&IBIC_pass $=$ dgeia_mce\&NOMBREENTIDAD $=$ * (accessed October 29, 2020).

Senigaglia, V., Christiansen, F., Bejder, L., Gendron, D., Lundquist, D., Noren, D. P., et al. (2016). Meta-analyses of whale-watching impact studies: comparisons of cetacean responses to disturbance. Mar. Ecol. Prog. Seri. 542, 251-263. doi: 10.3354/meps11497 
Senigaglia, V., Williams, R., and Lusseau, D. (2011). Influence of Perceived Predation Risk on Foraging Behaviour Among Different Social Groups in Northern Fish-Eating Killer Whales. Ph. D. Thesis, Aberdeen University, Aberden.

Sprogis, K. R., Bejder, L., Hanf, D., and Christiansen, F. (2020). Behavioural responses of migrating humpback whales to swim-with-whale activities in the Ningaloo Marine Park, Western Australia. J. Exp. Mar. Biol. Ecol. 522, 151254. doi: 10.1016/j.jembe.2019.151254

Swartz, S. L. (2018). “The gray whale (Eschrichtius robustus)," in Encyclopedia of Marine Mammals, eds B. Würsig, J. G. M. Thewissen, and K. Kovacs (San Diego, CA: Academic Press), 423-428. doi: 10.1016/b978-0-08-092372-7.50024-8

Urbán, R. J. (2010). "Marine mammals of the Gulf of California: an overview of diversity and conservation status," in The Gulf of California. Biodiversity and Conservation, ed. R. C. Brusca (Tucson, AZ: Arizona University Press), 188-209.

Urbán, R. J., Jaramillo, A. L., Aguayo, L. A., Ladrón de Guevara, P. P., Salinas, Z. M., Alvarez, F. C., et al. (2000). Migratory destinations of humpback whales wintering in the Mexican Pacific. J. Cetacean Res. Manag. 2, 101-110.

Urbán, R. J., Rojas-Bracho, L., Guerrero-Ruíz, M., Jaramillo-Legorreta, A., and Findley, L. T. (2005). "Cetacean diversity and conservation in the Gulf of California," in Biodiversity, Ecosystems, and Conservation in Northern Mexico, eds J. E. Cartron, G. Ceballos, and R. S. Felger (New York, NY: Oxford University Press), 276-297.

Urbán, R. J., Rojas-Bracho, L., Pérez-Cortés, H., Gómez-Gallardo, A., Swartz, S. L., Ludwig, S., et al. (2003). A review of gray whales on their wintering grounds in Mexican waters. J. Cetacean Res. Manag. 5, 281-295.

Urbán, R. J., Viloria-Gómora, L., Jiménez-López, E., Hidalgo, R. M., and MárquezBucio, E. (in press-b). "Propuesta de programa de protección regional del area de refugio de rorcuales de la región de loreto a Los Cabos, B.C.S," in Programas de Protección Regional de Áreas Prioritarias de Grandes Ballenas en el Golfo de California y Costa Occidental de Baja California Sur, eds R. J. Urbán and L. Viloria-Gómora (La Paz: Universidad Autónoma de Baja California Sur), $82-163$.

Urbán, R. J., Viloria-Gómora, L., and Martínez-Loustalot, P. (in press-a). "Propuesta de programa de protección regional del área de refugio de la ballena jorobada en la región de Los Cabos. B.C.S," in Programas de Protección Regional de Áreas Prioritarias de Grandes Ballenas en el Golfo de California y Costa Occidental de Baja California Sur, eds R. J. Urbán and L. Viloria-Gómora (La Paz: Universidad Autónoma de Baja California Sur), $164-221$.
Vargas-Bravo, M. H., Elorriaga-Verplancken, F. R., Olivos-Ortiz, A., MoralesGuerrero, B., Liñán-Cabello, M. A., and Ortega-Ortiz, C. D. (2020). Ecological aspects of killer whales from the Mexican Central Pacific coast: revealing a new ecotype in the Eastern Tropical Pacific. Mar. Mam. Sci. 2020, 1-16. doi: $10.1111 / \mathrm{mms} .12748$

Viloria-Gómora, L., Urbán, R. J., Manríquez, B. J. E., Jiménez-López, E., and Hidalgo, R. M. (in press). "Propuesta de programa de protección regional del área de refugio de la ballena gris en la región bahía magdalena a Laguna San Ignacio, B.C.S," in Programas de Protección Regional de Áreas Prioritarias de Grandes Ballenas en el Golfo de California y Costa Occidental de Baja California Sur, eds R. J. Urbán and L. Viloria-Gómora (La Paz: Universidad Autónoma de Baja California Sur), 18-81.

Walker, W. A. (1981). Geographic Variation in Morphology and Biology of Bottlenose Dolphins (Tursiops) in the Eastern North Pacific. Washington, DC: NOAA.

Weller, D. W., Klimex, A., Bradford, A. L., Calambokidis, J., Lang, A. R., Gisborne, B., et al. (2012). Movements of gray whales between the western and eastern North Pacific. Endanger. Species Res. 18, 193-199. doi: 10.3354/esr 00447

Wells, R. S., and Scott, M. D. (2018). "Bottlenose dolphin: common bottlenose dolphin, Tursiops truncatus," in Encyclopedia of Marine Mammals, 3rd Edn, eds B. Würsig, J. G. M. Thewissen, and K. Kovacs (Cambridge, MA: Academic Press), 118-125. doi: 10.1016/b978-0-12-804327-1.00072-8

Wildlife Connection ${ }^{\circledR}$ (2020). Expediciones con Delfines y Ballenas. Available online at: http://www.wildlifeconnection.com/dolphins-tour/ (accessed October 29, 2020).

Williams, R., Trites, A. W., and Bain, D. E. (2002). Behavioural responses of killer whales (Orcinus orca) to whale-watching boats: opportunistic observations and experimental approaches. J. Zoo. 256, 255-270. doi: 10.1017/ s0952836902000298

Conflict of Interest: The authors declare that the research was conducted in the absence of any commercial or financial relationships that could be construed as a potential conflict of interest.

Copyright (c) 2021 Urbán and Viloria-Gómora. This is an open-access article distributed under the terms of the Creative Commons Attribution License (CC BY). The use, distribution or reproduction in other forums is permitted, provided the original author(s) and the copyright owner(s) are credited and that the original publication in this journal is cited, in accordance with accepted academic practice. No use, distribution or reproduction is permitted which does not comply with these terms. 